\title{
CIPTA KARYA SENI PERTUNJUKAN TEATER ANAK BERBASIS KEBUDAYAAN PANJI (Best Practice Penciptaan Karya Seni Pertunjukan pada Masa Pandemi Covid-19)
}

\author{
Wahyudi $^{1}$, Ayu Titis Rukmanawati ${ }^{2}$, Kukuh Andri Aka ${ }^{3}$ \\ wahyudi@unpkdr.ac.id ${ }^{1}$, ayutitis@unpkediri.ac.id ${ }^{2}$, kukuh.andri@unpkediri.ac.id ${ }^{3}$ \\ PGSD, FKIP, Universitas Nusantara PGRI Kediri ${ }^{13}$ \\ PGPAUD, FKIP, Universitas Nusantara PGRI Kediri ${ }^{2}$
}

\begin{abstract}
Abstrak: artikel ini akan dibahas terkait best practice pengembangan dan proses validasi penciptaan "karya seni pertunjukan teater anak berbasis kebudayaan Panji" yang mengadopsi dari kisah Panji dan memiliki nilai kebaharuan pada masa pandemi Covid-19. Penelitian pengembangan penciptaan karya seni ini dilakukan melalui tahap konseptual, operasional, dan validasi ahli. Tahap konseptual meliputi (1) penulisan naskah, (2) merancang desain pertunjukkan, (3) pembuatan desain gerak, (4) pembuatan desain music, (5) pembuatan desain properti, dan (6) pembuatan desain artistik/setting; Tahap operasional meliputi (1) casting aktor, (2) proses pembuatan pertunjukkan secara keseluruhan, dan (3) tata rias dan busana. Melalui proses validasi ahli, produk dinyatakan memiliki tingkat originalitas, kebaharuan, dan keterterapan karya yang tinggi/valid untuk digunakan.
\end{abstract}

Kata kunci: cipta karya seni, teater anak, kebudayaan Panji, praktik terbaik, covid-19

\section{CHILDREN'S THEATER PERFORMANCE ART WORKS BASED ON PANJI CULTURE (Best Practices for Creating Performing Art Works during the Covid-19 Pandemic)}

\begin{abstract}
This article will discuss the best practices for developing and validating the creation of "Panji culture-based children's theater performance works" which adopt the Panji story and have novelty values during the Covid-19 pandemi. Research on the development of the creation of art works is carried out through the conceptual, operational, and expert validation stages. The conceptual stage includes (1) writing a script, (2) designing the show design, (3) making motion designs, (4) making music designs, (5) making property designs, and (6) making artistic designs/settings; The operational stage includes (1) casting actors, (2) the process of making the show, and (3)
\end{abstract}


Wahyudi, Ayu, Kukuh. Cipta Karya Seni Pertunjukan...

make-up and clothing. Through the expert validation process, the product is declared to have a high level of originality, novelty, and applicability of the work/is valid for use.

Keywords: creation of works of art, children's theater, Panji culture, best practice, covid-19

\section{PENDAHULUAN}

Sering kita mendengar masa siswa sekolah dasar adalah masa-masa emas. Pada saat ini pertumbuhan dan perkembangan mereka pada titik puncaknya. Untuk membentuk siswa yang utuh, maka dalam dunia pendidikan di sekolah dasar mereka tidak hanya dikembangkan aspek akademiknya saja, namun perlu dikembangkan aspek lainnya, misal aspek olah rasa (Yamin \& Kiptiah, 2016). Olah rasa ini diimplementasikan melalui pendidikan seni, baik seni rupa, maupun seni pertunjukan (Kusumastuti, 2020).

Permasalahan pertama yang ditemui terkait pendidikan seni antara lain jarang ditemui literasi alternatif bentuk-bentuk kesenian untuk siswa sekolah dasar berbasis kebudayaan lokal mereka (permasalahan di sekolah-sekolah eks Karisedinan Kediri), padahal jika produk-produk kesenian tersebut bernuansa kebudayaan-kebudayaan lokal, akan lebih menambah nilai kebermaknaan produk tersebut, misal mengelaborasikan kisah-kisah Panji (Kediri) kedalam sebuah karya seni. Kisah tentang panji akhir-akhir ini telah marak dikembangkan oleh berbagai lembaga baik pemerintahan, maupun independen (Ilahi, 2019; Manuaba, 2013). Ironinya, kisah panji belum banyak menyentuh pada aspek dunia anak, sehingga anak cenderung menjadi penonton semata tanpa terlibat langsung sebagai pengguna seni.

Permasalahan kedua adalah dalam keseharian pendidikan seni, siswa lebih banyak diajak untuk menjadi subjek "pengguna seni", ketimbang belajar menjadi "pencipta seni". Pelibatan anak dalam pengembangan aspek seni budaya sangat penting untuk diberdayakan agar anak mempunyai kepekaan estetik, nilai-nilai moral dan mencintai budaya sendiri. Saat ini, kegiatan yang berbasis kearifan lokal agaknya dianggap sebagai hal yang menjenuhkan dikalangan anak sekolah dasar, salah satu contohnya musik gamelan. Alih-alih untuk belajar bermain gamelan, anak-anak berkenan mendengarkan dan melihat saja sudah luar biasa. Untuk itu sangat diperlukan adanya sebuah upaya berupa gagasan dan tindakan dalam rangka membumikan kearifan 
Wahyudi, Ayu, Kukuh. Cipta Karya Seni Pertunjukan...

lokal (misal budaya Panji) kepada anak-anak dengan melibatkannya dalam proses kreatif. Mengenalkan kearifan lokal kepada anak-anak bukan untuk menjadikan dia sebagai seniman, melainkan untuk belajar tentang nilai-nilai estetika, etika dan culture kepada anak sejak dini.

Untuk itu peneliti merencanakan sebuah konsep seni pertunjukkan teater anak yang di dalamnya juga terdapat unsur musik dan tari yang kekinian agar dapat dimainkan dan dinikmati anak-anak dengan penuh keceriaan. Anak akan terlibat langsung dalam berproses kreatif dan juga benar-benar dapat merasakan estetika budaya nusantara yang adiluhung (Sunarya, 2012). Seni Pertunjukkan teater anak dirasa sangat kompleks untuk mewadai proses kreatif bersama antara peneliti dan anak-anak. Selain itu dalam teater terdapat aspek dialog yang setidaknya mudah dipahami dari pada aspek bunyi pada musik dan gerak pada seni tari.

Berdasarkan keadaan di atas, dalam artikel ini akan dibahas terkait best practice pengembangan dan proses validasi penciptaan "karya seni pertunjukan teater anak berbasis kebudayaan Panji” yang mengadopsi dari kisah Panji dan memiliki nilai kebaharuan pada masa pandemic covid-19. Aspek kebaharuan pada penelitian pengembangan cipta karya seni ini adalah pada bentuk penyajian pertunjukannya. Tujuan dari penelitian ini ialah untuk mendekatkan kebudayaan panji (kearifan lokal) terhadap anak sekolah dasar melalui seni pertunjukkan teater. Selain itu juga bertujuan untuk mengenalkan kesenian-kesenian tradisi seperti karawitan, tari dan teater dalam sajian yang lebih kekinian. Penyajian pertunjukannya nanti akan dikolaborasikan dengan unsur seni yang lain, seperti seni tari, seni musik, dan seni pedalangan. Keberagaman unsur-unsur seni tersebut akan dirangkai dalam satu cerita yang berpijak pada "Epos Panji". Cerita yang dijadikan pijakan ialah tentang ketokohan seorang panji sebagai satria yang jujur, mandiri, bertanggung jawab dan memiliki kepekaan sosial tinggi. Cerita tersebut akan dikemas dalam karakter anak-anak. Selain itu, produk ini juga akan menampilkan praktik terbaik yang dilakukan peneliti, untuk tetap berkarya pada masa pandemi Covid-19. 
Wahyudi, Ayu, Kukuh. Cipta Karya Seni Pertunjukan...

METODE

\section{Prosedur Penciptaan Karya}

Ditinjau dari tujuannya penelitian ini merupakan pengembangan cipta karya seni pertunjukan teater anak. Pendekatan yang digunakan dalam proses pembuatan karya ini adalah budaya Panji. Lokasi penelitian ini berada di SDN Jombatan 3 Jombang dengan subjek penelitian pengembangannya adalah anak kelas 4, 5 dan 6. Proses penciptaan karya ini terbagi menjadi 2 bagian yakni Tahap konseptual dan Operasional.

Dalam proses pembuatan karya seni, konsep adalah hal terpenting yang menjadi acuan dalam berkarya dan menjadi dasar sebuah pemikiran. Pada pengembangan dan penciptaan karya ini, konsepnya adalah mereinterpertasi cerita Panji dari Kediri ke dalam dunia anak. Berikut tahapan proses penciptaan diuraikan di bawah ini.

\section{Tahap Konseptual}

Cerita panji memang banyak berkisah tentang asmara dan juga unsur politik antara dua kerajaan jenggala dan daha. Tentu tema tersebut dirasa kurang pas jika diterapkan untuk anak-anak. Sehingga perlu adanya interpertasi cerita yang dapat dimainkan oleh anak-anak. Dalam rancangan karya ini, cerita yang digunakan sebagai pijakan ialah tentang kepribadian seorang Panji. Panji dikenal sebagai seorang satria yang jujur, berwibawa, mandiri, cerdas dan berjiwa sosial yang tinggi. Karakter yang dimiliki panji tersebutlah yang dijadikan sebagai sumber inspirasi untuk membuat naskah yang akan diberi judul "Pandadaran Inukertapati". Dari gambaran konsep tersebut kemudian diwujudkan dengan pembuatan naskah dengan durasi 10-12 menit. Naskah yang sudah dibuat akan dijadikan pijakan untuk membuat desain musik, tata gerak, kostum, property, dan unsur pendukung yang lain. Jenis musik yang digunakan ialah gamelan jawa, sedangkan ragam gerak yang digunakan adalah mengembangkan dari ragam gerak tari pada pertunjukan wayang topeng.

Secara rinci, tahapan konseptual terdiri dari tahap (1) penulisan naskah, (2) merancang desain pertunjukkan, (3) pembuatan desain gerak, (4) pembuatan desain music, (5) pembuatan desain properti, dan (6) pembuatan desain artistik/setting.

\section{Tahap Operasional}

Proses penuangan konsep dilakukan secara bertahap pada masing-masing pemain yang terlibat baik sebagai pemusik, penari dan aktor. Pemahaman pemain terhadap jalannya cerita yang akan dimainkan merupakan kunci utama untuk dapat 
Wahyudi, Ayu, Kukuh. Cipta Karya Seni Pertunjukan...

menghayati karya yang dimainkan. Proses latihan dilakukan secara bertahap pada masing-masing pemain (kelompok musik, tari dan keaktoran) dengan berpedoman pada naskah yang sudah dibuat.

Seni pertunjukan ini merupakan kolaborasi unsur musik, teater, dan tari. Orisinalitas dan kebaharuan produk akan dilakukan uji oleh ahli. Pada masa pandemi ini proses latihan dilakukan secara daring via whatsaap dan google meet. Proses casting dan pembagian kelompok menjadi tiga bagian sudah dilakukan sebelum masa pandemi Covid-19 mewabah di negeri ini. Menyikapi hal tersebut maka proses latihan tidak dilakukan secara tatap muka, namun melaui daring. Proses latihan dilakukan dengan pembuatan musik pengiring/ilustrasi dengan memandu proses latihan melalui daring dan membagikan notasi yang dimainkan. Kemudian musik yang sudah jadi akan dijadikan sebagai pijakan untuk proses seni tari, dan keaktoran.

Secara lengkap tahap operasional ini terdiri dari tahap (1) casting aktor, (2) proses pembuatan pertunjukkan secara keseluruhan, dan (3) tata rias dan busana.

\section{Jenis Data \& Subjek Coba}

Pada penelitian dan pengembangan karya seni ini, data yang akan dianalisis, adalah data originalitas, kebaharuan, dan keterterapan karya. Data tersebut akan diperoleh dari hasil penilaian ahli yang memiliki latar belakang ahli seni. Adapun identitas ahli tersebut adalah Dr. Setyo Yanuartuti, M. Si., sebagai ahli Seni Tari dan Nanda Sukmana, M.Pd., sebagai ahli Seni Teater.

\section{Instrumen}

Instrumen pada penelitian ini adalah angket lembar penilaian karya seni, dimana akan diuji aspek tingkat originalitas, kebaharuan, dan keterterapan karya menggunakan skala Likert. Adapun kisi-kisi intrumen tersebut ditampilkan pada tabel 1 di bawah ini.

Tabel 1. Kisi-kisi kevalidan produk

\begin{tabular}{|c|}
\hline Indikator \\
\hline Keorisinalitasan Karya \\
\hline Kebaruan cerita/lakon yang disajikan \\
\hline Kesesuaian Judul dengan karya seni pertunjukkan \\
\hline Keutuhan sajian karya seni \\
\hline Kebaharuan Karya \\
\hline Kesesuaian musik pengiring dalam alur cerita/lakon \\
\hline Kesesuaian gerak tari dalam alur cerita/lakon \\
\hline Kesesuaian artistik dengan sajian alur cerita/lakon \\
\hline
\end{tabular}


Wahyudi, Ayu, Kukuh. Cipta Karya Seni Pertunjukan...

\begin{tabular}{|c|}
\hline Indikator \\
\hline Kesesuaian rias dan busana \\
\hline Kesesuaian Dinamika musik iringan dengan dialog \\
\hline Kesesuaian pola lantai dengan penataan adegan \\
\hline Keterterapan Karya \\
\hline Kesesuaian cerita dengan budaya panji \\
\hline Kesesuaian Alur Cerita/Lakon dengan karakter siswa Sekolah \\
Dasar \\
\hline Nilai-nilai moral yang terkandung dalam cerita \\
\hline Kesesuaian tingkat kerumitan karya dengan siswa sekolah dasar \\
\hline
\end{tabular}

*) Tiap indikator diukur menjadi lima skala

\section{Prosedur dan Teknik Analisis Data}

Analisis data pada penelitian ini menggunakan teknik kualitatif deskriptif, yaitu data berupa skor perolahan dari ahli dan saran akan ditelaah serta dilakukan kajian untuk perbaikan karya seni.

\section{PEMBAHASAN}

\section{Tahap Konseptual}

\section{Penulisan Naskah}

Proses penulisan naskah dilakukan dengan merujuk pada cerita-cerita panji yang disesuaikan dengan karakter siswa sekolah dasar. Intisari dari naskah pertunjukkan ini ialah tentang perlombaan memanah. Dimana panji sebagai seorang anak yang dijagokan akan memenangkan lomba memanah, sehingga beberapa teman-temannya yang iri hati berupaya untuk merusak gendewo (busur) milik Panji agar tidak dapat mengikuti lomba memanah. Karena sifat panji yang berjiwa sabar, welas asih, dan selalu bersikap baik akhirnya Panji diberi gendewo oleh Demang yang merupakan sahabat sejatinya. Akhir cerita, Panji memenangkan lomba memanah dan memaafkan kejahilan teman-temannya. Ide dasar membuat cerita tersebut ialah menerjemahkan dari sifat-sifat baik tokoh Panji/ Inu Kertapati yang dapat dijadikan suri tauladan.

Pembuatan plot pada pertunjukkan ini terbagi menjadi 4 bagian. Bagian pertama pembuka oleh Dalang yang dilakukan dengan tembang-tembang pitutur, bagian kedua adalah ilustrasi gendewa Inu Kertapati yang dicuri tokoh antagonis, bagian ke 3 adalah rumah Demang (sahabat akrab Panji), dan bagian ke 4 adalah tempat lomba memanah.

\section{Merancang Desain Pertunjukkan}


Wahyudi, Ayu, Kukuh. Cipta Karya Seni Pertunjukan...

Pada karya ini melibatkan 3 unsur seni yakni seni teater, seni tari dan seni karawitan/musik.
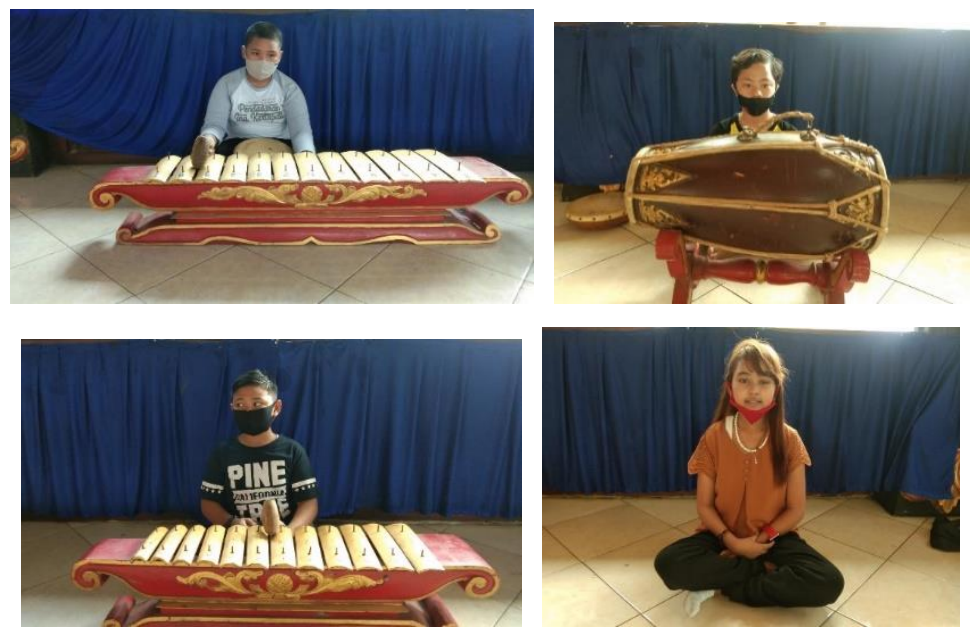

Gambar 1,2,3,dan 4. Proses Latihan

\section{Pengembangan Desain Gerak}

\section{Bagian Pertama}

(1) Dalang membuka cerita, memohon kepada Sang Pencipta agar pagelaran terlaksana dengan lancar tanpa ada satu kendala apapun.

(2) Suasana semangat untuk berlatih memanah Inu Kertapati bersama dengan temantemanya ditempat latihan.

Rancangan garap gerak: Eksplorasi properti Gendewa dengan gerak-gerak latihan memanah memakai karakter gerak putra gagah seperti kaki tanjak (pose kuda-kuda), pergerakan tangan memainkan busur panah (Gendewa). Vocabuler gerak tetap mengacu pada gerak-gerak ayang Topeng Vocabuler gerak tetap mengacu pada gerak-gerak Wayang Topeng Jati Dhuwur Jati Dhuwur Jombang untuk memperkuat ciri khas kedaerahan atau lokal genius daerah.

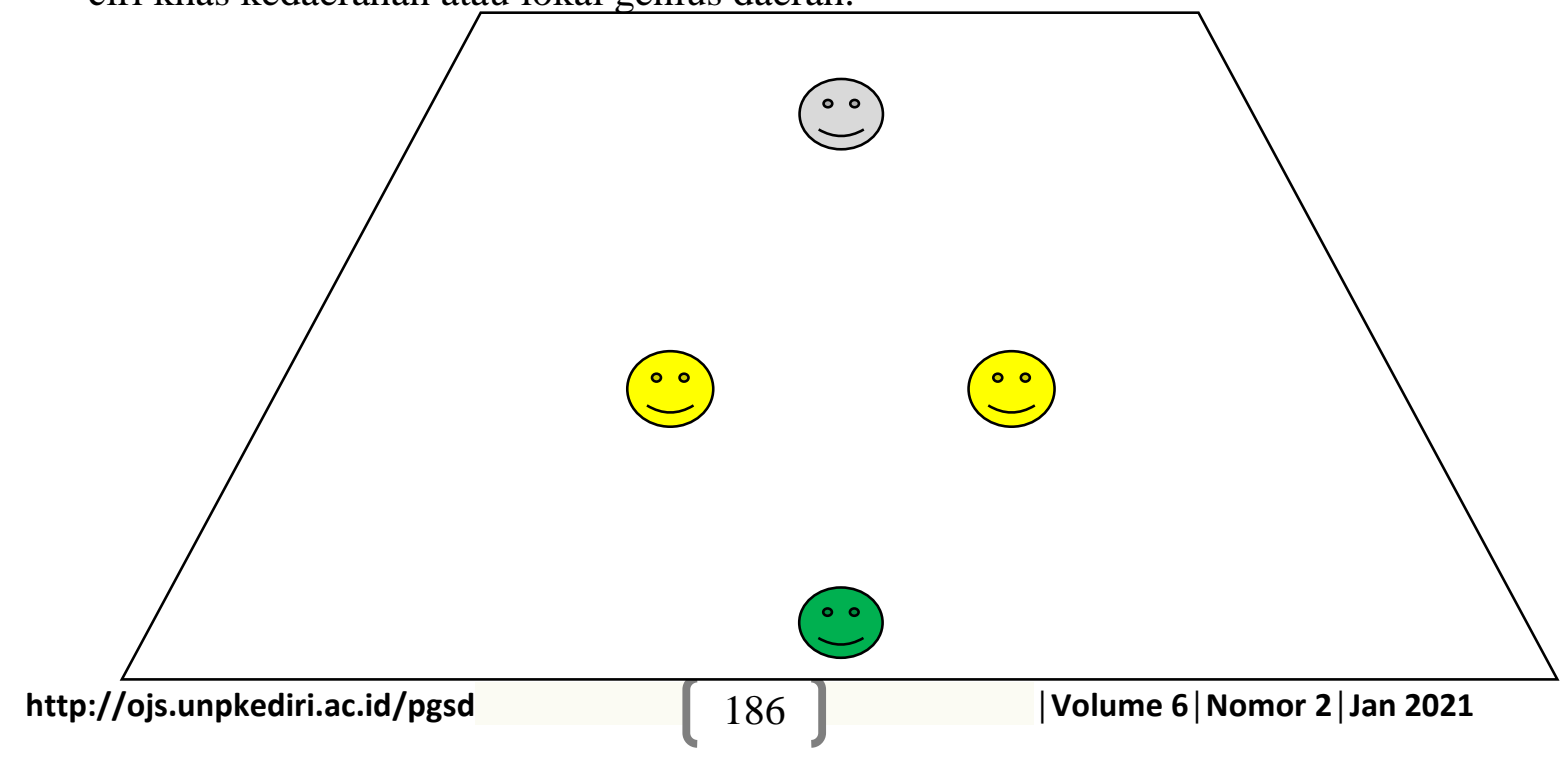


Wahyudi, Ayu, Kukuh. Cipta Karya Seni Pertunjukan...

Gambar 5. Rancangan Gerak bagian Pertama (1)

(3) Tiba-tiba muncul teman Inu Kertapati yang memiliki sifat iri dan dengki merebut Gendewa Inu Kertapati dan kemudian merusaknya hingga tidak dapat digunakan kembali. Susana menegang penuh dengan amarah,

Rancangan garap gerak menyesuaikan dengan dialog antara aktor Inu Kertapati dan Tokoh Antagonis (teman Panji yang iri dan dengki). Gerak para teman Panji hanya pose karena terkejut karena Gendewa dari Inu Kertapati yang dirusak oleh Tokoh Antagonis.

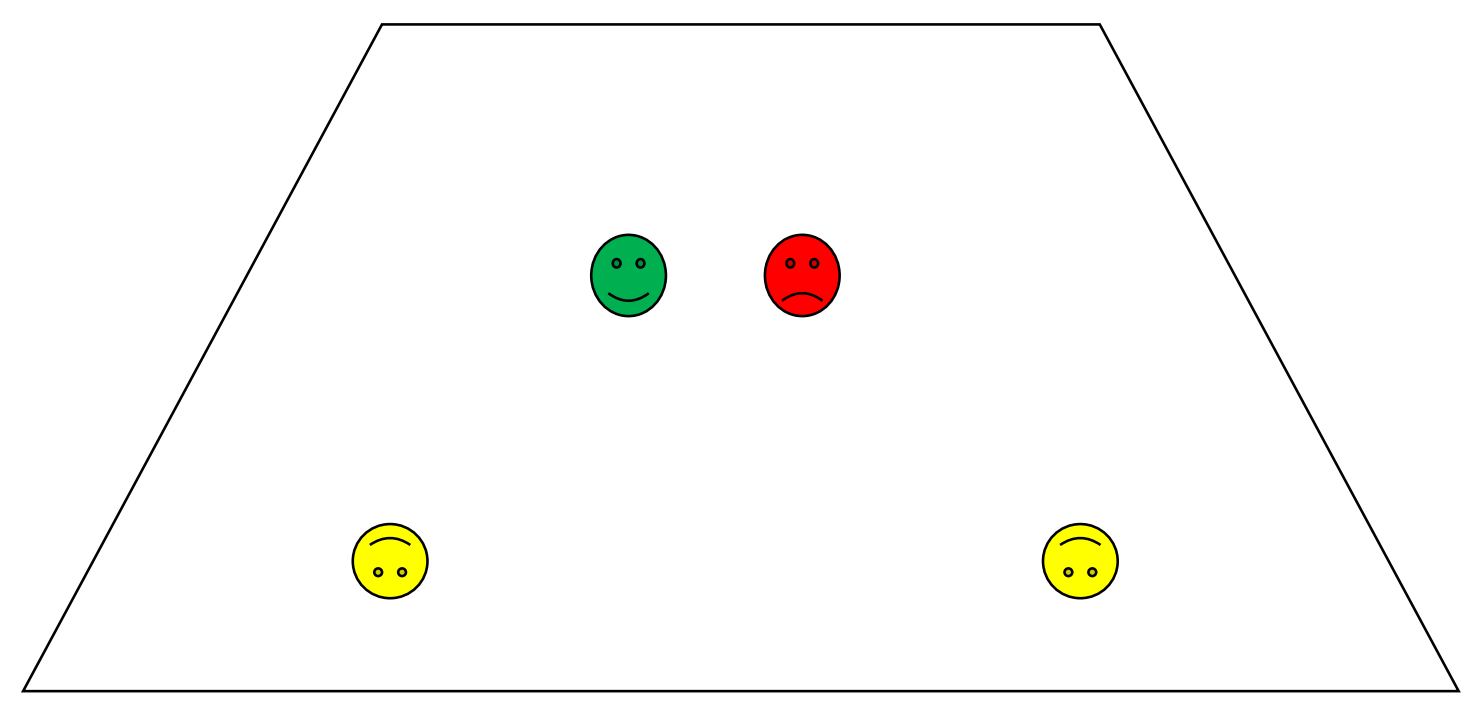

Gambar 6. Rancangan Gerak bagian Pertama (2)

\section{Bagian Kedua}

(1) Di tempat yang lain, di depan rumah Demang.

Demang merupakan utusan Ayah Inu Kertapati untuk mengasuh dan menjaga Inu Kertapati. Demang memiliki karakter lucu, menghibur dan setia.

Rancangan garap gerak : Demang mengacu pada gerak-gerak yang menimbulkan kesan jenaka menyesuaikan dengan dialog, syair lagu dan musik yang digarap terlebih dahulu pada bagian ini. Gerak hanya mengisi pada penambahan karakter Demang saja sehingga pemeran diberi kebebasan mengeksplor gerak tubuh menyesuaikan dengan konsep adegan. 
Wahyudi, Ayu, Kukuh. Cipta Karya Seni Pertunjukan...

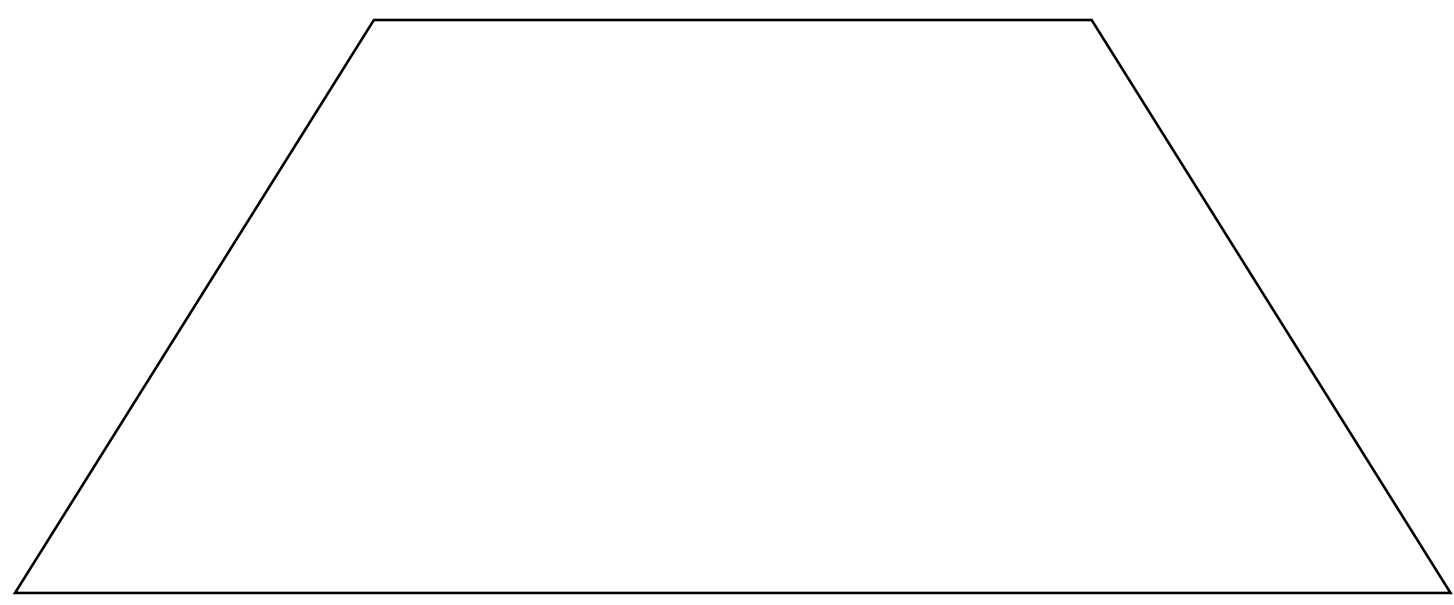

Gambar 7. Rancangan Gerak bagian Kedua (1)

(2) Panji datang menangis untuk meminta tolong kepada Demang. Suasana haru, sedih dan keewa

Rancangan garap gerak : Panji datang berjalan terkeyoh-keyoh kemudian terjatuh/tersungkur. Demang terkejut melihat Panji terjatuh dan menangis. Walaupun Demang adalah orang kepercayaan dan utusan Ayahanda Inu Kertapati namun tetap sikapnya sopan dan penuh etika menghadapi tuannya. Begitu melihat Inu terjatuh Demang langsung duduk menyembah pada tuannya.

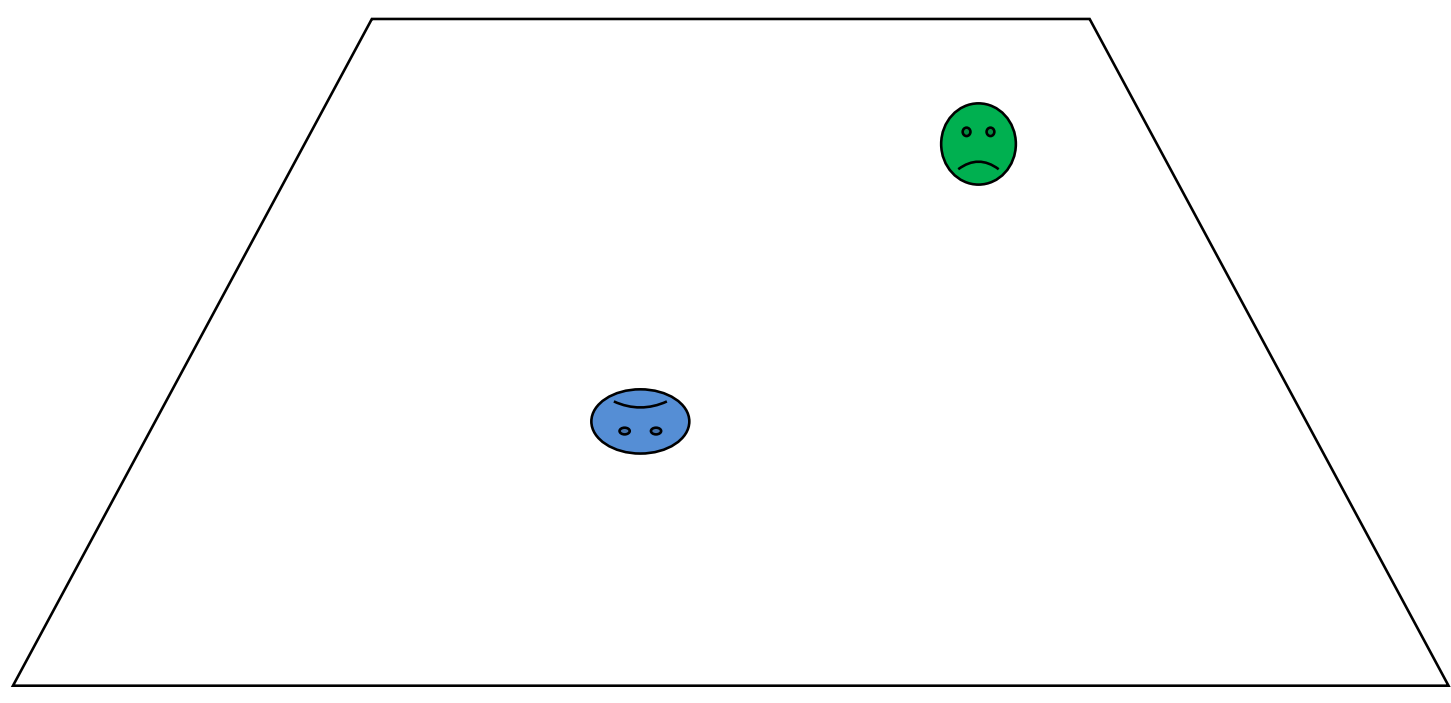

Gambar 8. Rancangan Gerak bagian Kedua (2) 
Wahyudi, Ayu, Kukuh. Cipta Karya Seni Pertunjukan...

(3) Datang teman-teman Inu Kertapati membawa kabar kurang baik yaitu tidak dapat menangkap Tokoh Antagonis yang telah berbuat jahat terhadap Inu.

Rancangan Garap Gerak: Datang teman Inu dengan berlari dan berteriak memanggil Inu, kemudian pose Jengkeng atau menyembah sambil dialog (menjelaskan bahwa tidak berhasil menangkap Tokoh Antagonis. Inu Kertapati bergerak srisig menghampiri teman-temannya dengan raut bahagia bahwa dia sudah mendapat bantuan dari Demang dengan diberikannya Gendewa lagi, sehingga dapat mengikuti ujian memanah.

Dengan munculnya semangat Inu Kertapati kembali maka diwujudkan dengan garap gerak semangat disertai nyanyian/vokal dari Inu kertapati untuk merayakan munculnya semangat baru dalam dirinya. Gerak disesuaikan dengan nyanyian dari Inu Kertapati, teman-teman Inu mengikuti grak dari Inu. Kemudian diteruskan gerak budhalan yang diadopsi dari ayang Topeng Jati Dhuwur Jombang. Gambaran dari gerak budhalan adalah proses pemberangkatan untuk mengikuti lomba memanah.

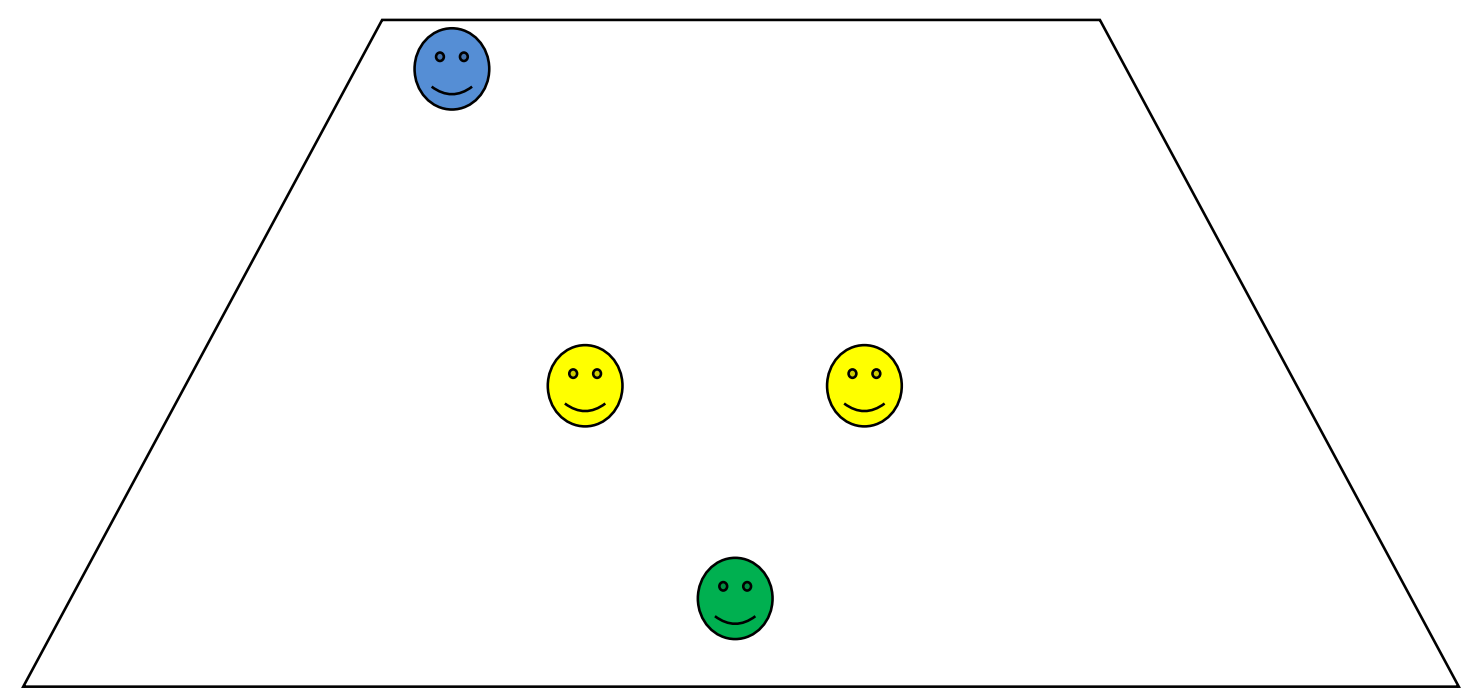

Gambar 9. Rancangan Gerak bagian Kedua (3)

\section{Bagian Ketiga}

(1) Suasana beralih di sebuah tempat ujian memanah. Semuanya sudah siap, dengan penuh kebahagiaan dari Tokoh Antagonis dan teman-temannya karena meyakini Inu Kertapati tidak dapat mengikuti ujian memanah.

Rancangan garap gerak : Diawali dengan dialog Tokoh Antagonis yang sedang bebahagia, kemudian disahut oleh teman-temannya dengan gerak yang 
Wahyudi, Ayu, Kukuh. Cipta Karya Seni Pertunjukan... mengungkapkan rasa kemenangan dan kebahagiaan.

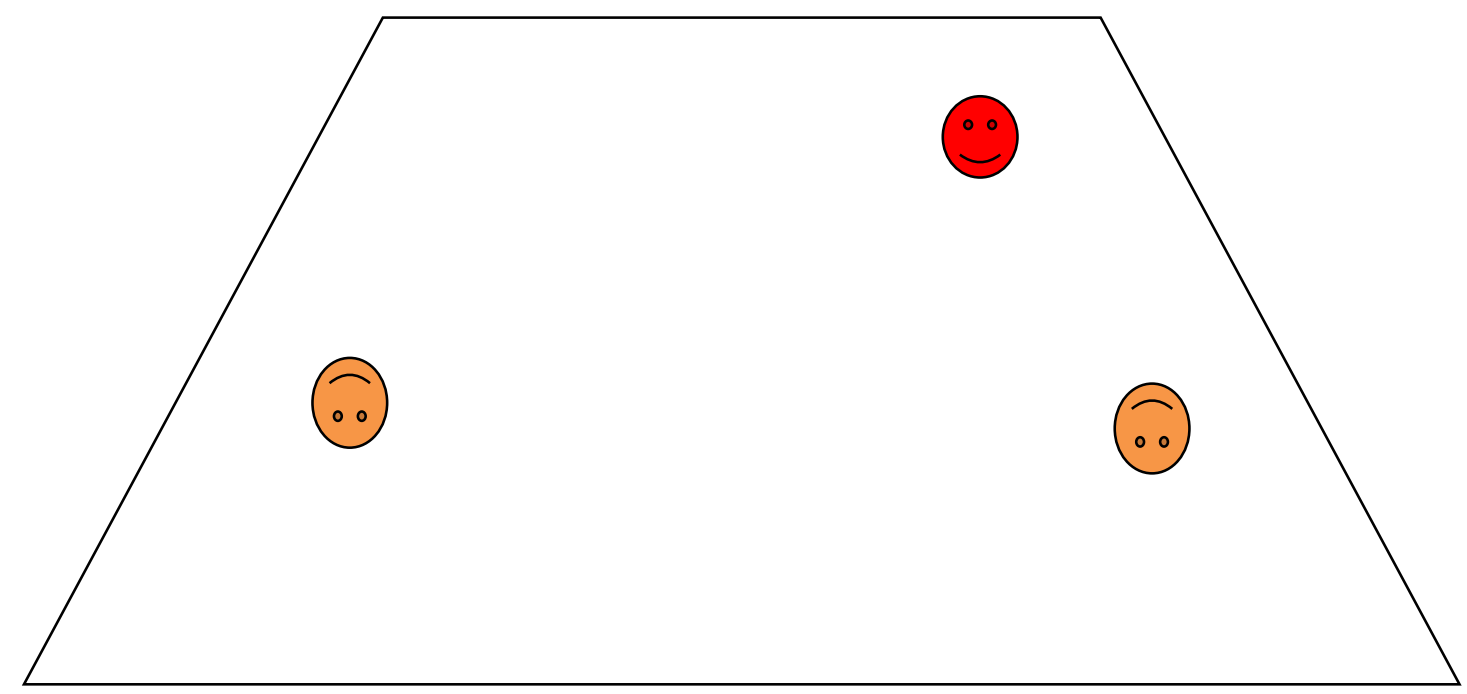

Gambar 10. Rancangan Gerak bagian Ketiga (1)

(2) Datang Inu kertapati bersama temannya, susasana menjadi tegang dan penuh amarah.

Rancangan Garap Gerak : Tokoh Antagonis merasa tidak terima atas kedatangan kembali Inu Kertapati untuk mengikuti ujian memanah kemudian meminta teman-temannya untuk menyerang Inu Kertapati dan teman-temannya. Perwujudan gerak dengan menggunakan gerak simbol peperangan yang saling menyerang namun tidak anarkis tetap berpedoman pada etika dan estetika untuk pemeran anak-anak.

Teman dari tokoh antagonis kalah, Inu memberi nasihat kepada teman-temannya yang penuh rasa iri dan dengki untuk beruba lebih baik dengan melalui tembang. Kemudian Inu menunjukkan kepada teman-temannya kemampuan memanahnya yang didasari dengan kejujuran dengan penuh energi positif, sehingga hasilnya pun Inu berhasil. 
Wahyudi, Ayu, Kukuh. Cipta Karya Seni Pertunjukan...

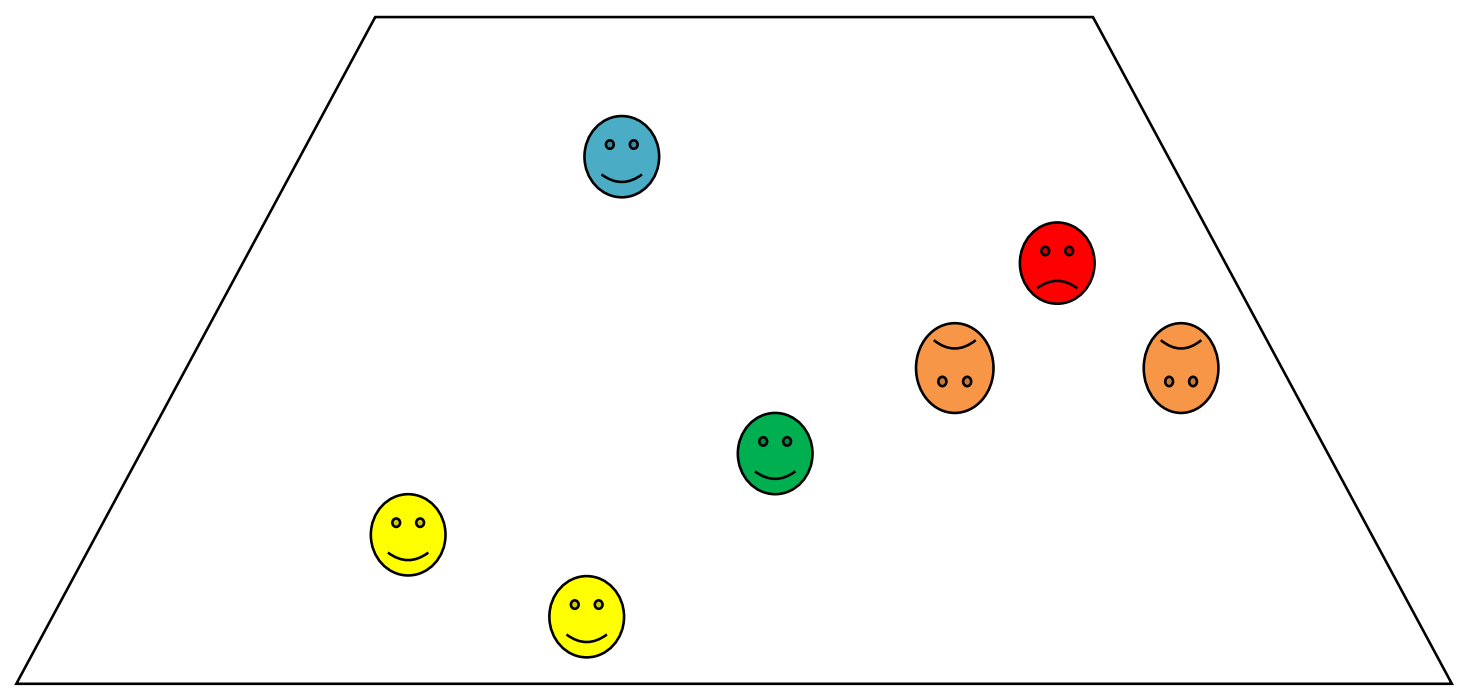

Gambar 11. Rancangan Gerak bagian Ketiga (2)

Keterangan :

: Inu Kertapati/Panji
$:$ Teman Inu Kertapati

\section{Pengembangan Desain Musik}

Proses pembuatan musik iringan dilakukan dengan memilah jenis musik menjadi dua bagian. Bagian pertama ialah pembuatan musik sebagai iringan tari. Pada tahapan ini musik menyesuaikan dengan aksen-aksen gerak para penari. Sedangkan pada bagian kedua ialah musik ilustrasi. Dalam pertunjukkan ini terdapat dua suasana yang di iringi menggunakan musik yang berjenis ilustrasi, yakni pada bagian kesedihan inukertapati, ketegangan antara inu kertapati dan tokoh antagonis.

\section{Pembuatan Desain Properti}

Properti yang digunakan dalam pertunjukkan ini ada dua jenis. Property yang pertama ialah gendewa yang juga merupakan unsur pendukung utama dalam 
Wahyudi, Ayu, Kukuh. Cipta Karya Seni Pertunjukan...

pertunjukkan ini. Sedangkan propety kedua ialah gunungan yang dimainkan oleh dalang. Penggunaan property gunungan mengadopsi dari pertunjukkan wayang kulit yang mana bagian pembukaanya selalu diawali dengan memainkan gunungan.

\section{Pembuatan Desain Artistik/Setting}

Seting yang digunakan dalam pertunjukkan ini menggunakan tiga jenis trap (level). Dua level berbentuk asimetris dan satu level simetris. Level asimetris digunakan untuk memperkuat suasana yang dinginkan dalam setiap pengadeganan.

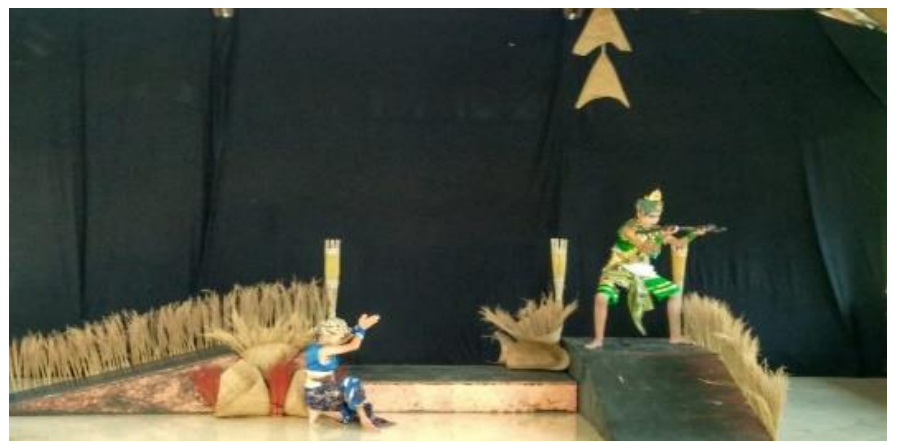

Gambar 12. Desain Artistik/Setting

\section{Tahap Operasional}

\section{Casting Aktor, Pemusik, dan Penari}

Proses casting pemain dilakukan dengan cara menyeleksi basic keterampilan yang dimiliki oleh masing-masing siswa. Pemain teater (aktor) diseleksi dengan mempertimbangkan kualitas vokal, ekspresi, dan keberanian dalam berdialog. Pemain Tari di seleksi dengan cara menguji kelenturan tubuh, dan keluwesan gerak. Pada pemain musik diseleksi dengan cara menguji kepekaan irama.

\section{Proses Pembuatan Pertunjukkan secara Keseluruhan}

Proses awal dari penciptaan seni pertunjukkan "Gendewa Inu Kertapati” ini ialah dengan menjelaskan alur cerita dan nama-nama tokoh yang ada dalam pertunjukkan tersebut. Seluruh pemain diberikan pemahaman yang sama baik aktor, penari maupun pemusik tentang alur cerita yang akan disajikan. Dalam sajian pertunjukkan ini baik aktor, penari dan pemusik memiliki keterpaduan yang kuat. Keterpaduan yang dimaksud ialah, sebagai aktor tidak hanya tentang berdialog semata, namun juga harus menari dan nembang, kemudian juga untuk penari selain menari juga ada bagian-bagian tertentu yang harus berdialog. Begitu pula dengan pemusik, tidak 
Wahyudi, Ayu, Kukuh. Cipta Karya Seni Pertunjukan...

sekedar memainkan musik untuk mengiringi tari dan ilustrasi, namun juga ada dialogdialog yang harus dilakukan.

Kelompok aktor. Tahapan latihan yan dilakukan oleh kelompok aktor adalah, reading, bloking, dan penjiwaan. Proses reading dilakukan dengan membaca naskah namun dengan penekanan-penekanan karakter tokoh yang dimankan. Pada saat latihan bloking aktor diharuskan sudah hafal naskah, agar memudahkan menemukan desain pola lantai yang estetik. Pada tahap penjiwaan ini prosesnya dilakukan bersamaan dengan ilustrasi yang sudah dibuat oleh pemusik.

Kelompok Penari. Secara keseluruhan adegan tari dalam pertunjukkan ini terbagi menjadi 3 bagian. Bagian pertama adalah tari Ilustrasi proses gendewa inukertapati yang dicuri oleh temannya. Bagian kedua adalah budalan yakni tentang munculnya semangat inukertapati untuk mengikuti sayembara kembali setelah diberi gendewa oleh demang, bagian ke tiga adalah tentang ilustrasi kemenagan inukertapati tentang lomba memanah.

Ragam gerak yang digunakan dalam pertunjukkan merujuk pada gerak dari kesenian wayang topeng jatiduwur jombang. Idiom-idiom gerak tersebut dieksplor sedemikian rupa dan disederhanakan agar lebih mudah dipelajari oleh siswa SD.

Kelompok pemusik. Proses kelompok pemusik dilakukan dengan memudahkan pola-pola teknik permainan karawitan orang dewasa kepada anak-anak. Dalam pertunjukkan ini musik karawitan yang digunakan mengacu pada karawitan gaya jawatimuran.

\section{Tata Rias dan Busana}

Pola tatarias dan busana yang digunakan dalam pertunjukkan ini mengadopsi dari kesenian wayang topeng jati duwur Jombang. Namun demikian, untuk menguatkan estetik visual rias dan busana tidak dibuat terlalu mencolok dan glamor. Rias dan busana juga mempertimbangkan keleluasaan siswa SD dalam berakting, bergerak ataupun bermusik. 


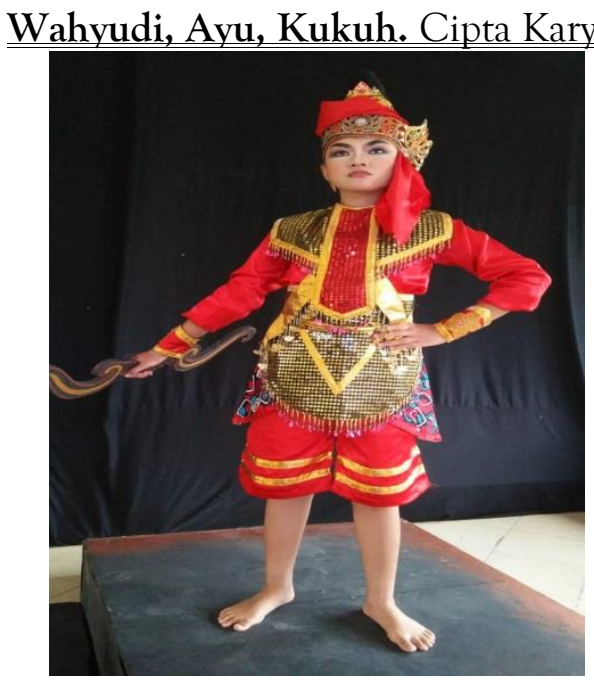

(Tokoh Antagonis)

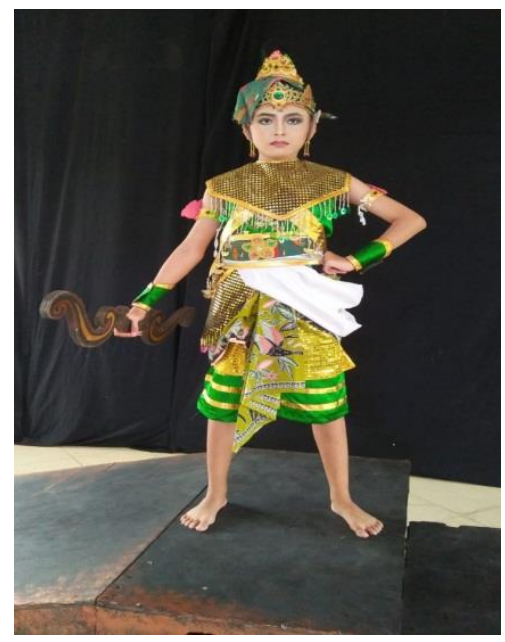

(Tokoh Inu Kertapati)

Gambar 13. Tata Rias dan Busana

\section{HASIL}

Untuk mendapatkan karya yang berkualitas, maka dilakukan proses validasi. Dari kegiatan validasi pertama oleh ahli seni tari, produk ini mendapatkan skor 4,60, artinya produk valid dengan revisi kecil, beberapa revisi dan perbaikannya adalah terkait dengan pola lantai penari. Pada validasi kedua mendapatkan skor 5, artinya produk dapat digunakan. Dari kegiatan validasi kedua oleh ahli seni pertunjukan teater, produk ini mendapatkan skor 4,56, artinya produk valid dengan revisi kecil, beberapa revisi dan perbaikannya adalah tentang bloking aktor dan tatanan artistik. Pada validasi kedua mendapatkan skor 5, artinya produk dapat digunakan.

Berdasarkan dari hasil validasi maka produk dapat digunakan yang artinya dapat dipublikasikan. Dalam penelitian ini hasil karya dipublikasikan melalui streaming youtube mengingat masih dalam kondisi pandemi covid 19.

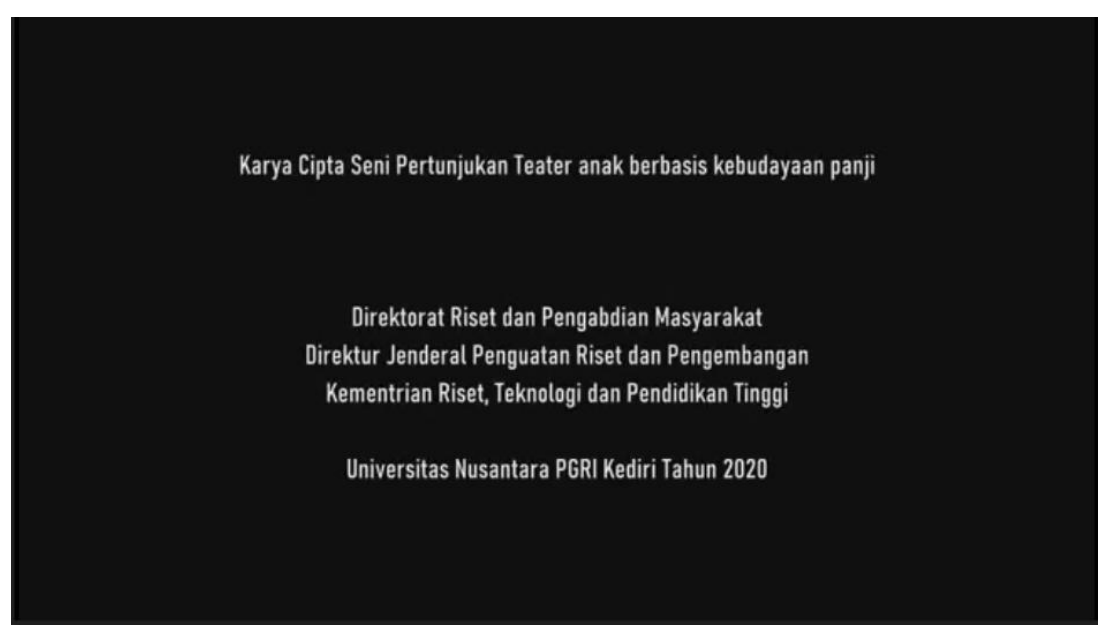


Wahyudi, Ayu, Kukuh. Cipta Karya Seni Pertunjukan...
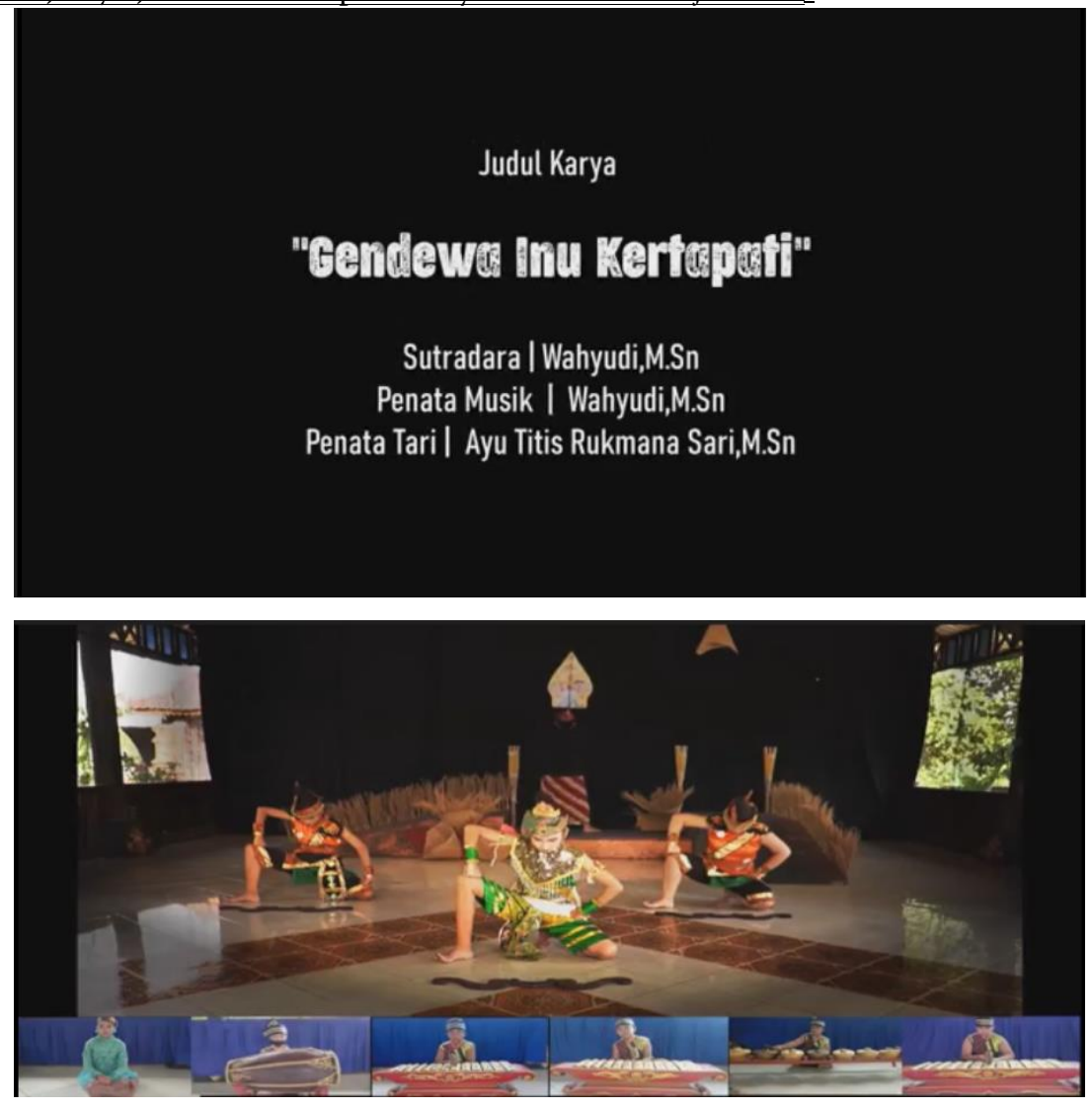

Gambar 14, 15, 16. Sampel Video Hasil Produk. Tetap berupaya menjaga protokol kesehatan pada masa pandemi covi-19

\section{SIMPULAN}

Melalui tahap konseptual yang meliputi (1) penulisan naskah, (2) merancang desain pertunjukkan, (3) pembuatan desain gerak, (4) pembuatan desain music, (5) pembuatan desain properti, dan (6) pembuatan desain artistik/setting, serta tahap operasional yang meliputi (1) casting aktor, (2) proses pembuatan pertunjukkan secara keseluruhan, dan (3) tata rias dan busana. Telah dihasilkan sebuah produk karya seni pertunjukan teater anak berbasis kebudayaan Panji. Produk ini merupakan hasil dari best practice penciptaan karya seni pertunjukan pada masa pandemi Covid-19. Melalui kedua proses validasi ahli, produk dinyatakan memiliki tingkat originalitas, kebaharuan, dan keterterapan karya yang tinggi/valid untuk digunakan. 
Wahyudi, Ayu, Kukuh. Cipta Karya Seni Pertunjukan...

\section{UCAPAN TERIMA KASIH}

Tim peneliti mengucapkan terima kasih yang tulus kepada semua pihak yang telah membantu hingga artikel ini diterbitkan. Penulis juga mengucapkan terima kasih kepada Universitas Nusatara PGRI Kediri yang telah mendukung kegiatan penelitian ini, khususnya terima kasih kepada Direktorat Riset dan Pengabdian Masyarakat (DRPM) Kementerian Riset dan Teknologi/Badan Riset dan Inovasi Nasional Republik Indonesia yang telah mendukung penelitian ini melalui pendanaan hibah Penelitian Dosen Pemula (PDP) tahun anggaran 2020.

\section{DAFTAR RUJUKAN}

Ilahi, N. 2009. "Upaya Kabupaten Jombang dalam Merawat Budaya Panji”, dalam Henri

Kusumastuti, E. 2020. Pendidikan Seni untuk Sekolah Dasar. Academia. edu.

Manuaba, I. B. (2013). Keberadaan dan bentuk transformasi cerita Panji. Litera, 12(1)

Murgiyanto, S. 2004. Tradisi dan Ino- vasi. Jakarta: Wedatama Widya Sastra

Nuryahyo, ed. Konservasi Panji. Surabaya-Malang: Dewan Kesenian Jawa Timur bekerjasama dengan Bayu Media Publising.

Soedarsono. 1986. Pengantar Pengetahuan dan Komposisi Tari. Jakarta: Direktorat Kesenian

Sumarjo, Y. (2001). Seni pertunjukan Indonesia: suatu pendekatan sejarah. STSI Press Bandung

Sunarya, I. K. (2012). Pendidikan Tinggi Seni Berkarakter Budaya Adiluhung Estafet Generasi Kreatif yang Berkelanjutan. Jurnal Pendidikan Karakter, (2)

Yamin, M., \& Kiptiah, M. (2016). Kajian Tentang Nilai-Nilai Karakter dalam Pembelajaran Bahasa Inggris Jurusan IPS Tingkat Sman Di Kota Banjarmasin. Scientia: Jurnal Hasil Penelitian, 1(2), 1-20.

Yanuartuti, S. (2015). Revitalisasi Pertunjukan Wayang Topeng Jati Duwur Jombang Lakon Patah Kuda Narawangsa (Doctoral dissertation, Institut Seni Indonesia Surakarta) 